\title{
РЕЛІГІЙНА ВІРА ЯК ЧИННИК ПОДОЛАННЯ КРИТИЧНИХ ЖИТТЕВИХ СИТУАЦІЙ
}

УдК: $234.2+159.96$.

\section{Предко Денис Єрофейович \\ Кандидат філософських наук, асистент кафедри загальної психології Київського національного уні- верситету імені Тараса Шевченка, м. Київ (Украӥна)}

\section{Ларін Дмитро Ігорович}

Аспірант кафедри загальної психології Київського національного університету імені Тараса Шевченка, м. Київ (Україна)

\begin{abstract}
Анотація. Висвітлюеться сенсожиттева спрямованість релігійної віри та виявляється ї̈ можливості в подоланні критичних життєвих ситуацій. Стверджується, щุо релігійна віра здатна пом'якшити чи подолати певні життєві ситуації, виступаючи інтегратором та мобілізатором особистісних ресурсів. Наголошується на терапевтичній функиії релігійної віри, яка задовольняє психологічні потреби індивіда, «пом'якиує» екзистенційну напругу, надає емоиійну розрядку $i$ заспокоєння, стабілізує душевний стан особистості. Фатальна особливість релігійної віри уможливлює ї̈ розгляд як складову особистісних ресурсів.
\end{abstract}

Ключові слова: релігійна віра, критична життєва ситуація, сенс життя, фатальність, особистісний ресурс.

Постановка проблеми. В умовах сучасних глобалізаційних процесів, коли предметний зміст ціннісного світу людини все більше урізноманітнюється, психологічна наука, використовуючи формування уявлень про психічний і духовний розвиток особистості в контексті транскультурального і багаторівневого підходу, дедалі частіше звертається до дослідження ірраціональних систем світовід- чуття, до тих духовних надбань, які дотичні до абсолютного сенсу, граничних основ рефлексуючого змісту буття.

У зв'язку з цим особливе місце в системі психологічного знання займає екзистенційно-духовна парадигма, яка розглядає розвиток і становлення особистості як творчий пошук людиною свого призначення, актуалізації своїх життєвих можливостей. Однак життєвий 
шлях особистості пов'язаний 3 проходженням різних критичних ситуацій, які здатні як інтегрувати ii, так і дезінтегрувати. Часто-густо таким психологічним конструктом стає релігійна віра, як унікальний імператив ідентичності особистості, завдяки якому вона прилучається до царини трансцендентного, можливості духовно збагатитися та пом'якшити чи подолати критичну життєву ситуацію.

Аналіз досліджень і публікацій. Сьогодні проблематика «людина в критичних ситуаціях» все активніше розробляється в психології особистості, соціальній психології, психотерапевтичній практиці тощо. Вивчення психологічного подолання важких життєвих ситуацій пов'язано з дослідженнями психологічного захисту (Г. Вайлант, Л. Вассерман, Ф. Василюк, Р. Грановська, І. Нікольська, Н. Хаан та ін.); психічної та соціальнопсихологічної адаптації (Ф. Березін, Л. Дика, С. Шапкін); подолання стресів (В. Бодров, А. Біллінг, С. Карвер, Р. Лазарус, У. Леєр, P. Моос, Г. Томе, Ш. Фолкман, М. Шейер); саморегуляції діяльності та поведінки, регулювання функціональних станів (В. Бодров, О. Конопкін, А. Леонова, В. Марищук, А. Прохоров, С. Сергіенко); активності і їі ролі в подоланні життєвих труднощів (Б. Ананьєв, К. Абульханова, А. Білоусова, Б. Ломов та ін.). Відтак у останній час появилося багато досліджень про критичні життєві ситуації, зокрема стрес, фрустрацію, конфлікт і кризу. Однак теоретичні уявлення про критичні си- туації розвинені досить слабо. Особливо це стосується проблеми дослідження взаємозв'язку релігійної віри та різних життєвих ситуацій, коли спостерігається порушення психічної, душевної, емоційної рівноваги. Мета нашого дослідження - 3'ясувати роль релігійної віри в критичних життєвих ситуаціях особистості.

Виклад основного матеріалу. Продуктивною для розуміння ролі релігійної віри, як чинника подолання критичних життєвих ситуацій, є думка М. Мамардашвілі про віднайдення людиною певної «точки опори» в житті, що уможливлює «виходити за межі будь-якої культури, будь-якої ідеології, будь-якого суспільства і знаходити підстави свого буття, які не залежать від того, що трапиться в часі із суспільством, культурою, ідеологією чи соціальним рухом. Це і $є$ так звані особистісні підстави» [4, с. 114]. За допомогою віри людина знаходить «точку опори», яка $\epsilon$, на переконання М. Мамардашвілі, запорукою і умовою «нерозпаду особистості» [4, с.114]. Перспективним у методологічному плані $є$ також підхід А. Козирєвої, яка вважає віру інтегральним станом людини, тобто таким, що цілісно охоплює всі аспекти людської особистості - розум, почуття і діяльнісний аспект психіки людини [2, с.154]. При цьому дослідниця зазначає, що емоційні, інтелектуальні і вольові теорії віри склалися саме завдяки традиційному поділові психіки людини. Однак, коли ми говоримо про віру, як стан індивіда, не варто 
виокремлювати в ній різні аспекти волі, думки та емоції, оскільки все це існує водночас і синкретично в єдиному акті віри. Ці елементи дійсно можуть утворюватися в акті віри в різних співвідношеннях, але, на нашу думку, переважання емоційних чи інтелектуальних стимулів залежить лише від індивідуальної психологічної конституції кожної конкретної особи, яка переживає стан віри. Навряд чи можна говорити про різні види віри. Коли ж йдеться про відчужене від індивіда існування віри, іiі доцільніше називати віруванням, підкреслюючи, що мається на увазі лише її змістовна сторона. Отже, потрібно розрізняти віру як психологічний акт, інтегральний стан людини та вірування, тобто формулювання, певний концептуально оформлений ідейний компонент.

Зазвичай найсильнішими критичними ситуаціями особистості $є$ ті, що пов'язані 3 усвідомленням власної смертності (невиліковна хвороба, участь в бойових діях тощо) або зіткнення зі смертю іншого (переживання втрати близької людини). Критична ситуація переживається особистістю порізному. 3 одного боку, вона може викликати руйнівну дію, підвищуючи тривогу і депресію, почуття безпорадності і безнадійності, що може привести до життєвої кризи, а з іншого надати сенс життю, зробити його більш повним і змістовним. У будь-якому випадку зіткнення з критичною ситуацією болісно переживається особистістю і змінює її ставлення до життя, смерті, себе і цінностей, що формує різні життєві стратегії, які допомагають людині вийти з критичної ситуації. Все зазначене вище дозволяє говорити про необхідність психологічної допомоги особам, які перебувають у критичній життєвій ситуації.

Безперечно, критичні ситуації змінюють ставлення особистості до життя, до самого себе, інших. Напрямок цих змін буде залежати від можливості особистості інтегрувати психотравмуючий досвід, пов'язаний з критичною ситуацією, а також від ставлення до самої ситуації. Тому й проблема взаємозв'язку релігійної віри та критичних життєвих ситуацій має багато зрізів. Ми спробуємо продемонструвати, що релігійна віра, сенс життя є, по суті, єдиним вузлом, завдяки якому розгортається життєва ситуація. Загальновідомо, що в основі релігійного світогляду лежить проблема життя та смерті, яка в багатьох релігійних системах стає проблемою «спасіння». Тобто «правильне життя» є запорукою «безсмертя» в тій чи іншій формі, власне, наповнення життя смислом, натомість «неправильне» - призводить до мук, смерті та всіляких негараздів.

За Д. Магнусоном [3, с.28-33], при аналізі ситуації іiі елементи можна поділити на дві групи. Першу групу Д. Магнусон називає власне визначаючі ситуаційні властивості - це складність, ясність, сила і сприяння. До другої групи відносяться властивості ситуації, пов'язані з людиною - це завдання, правила, ролі, цілі, очікування, мотивації. Продовжуючи розвиток ідеї про способи аналізу ситуації, автор 
пропонує рівні іiі аналізу: через зовнішні, об'єктивні прояви; через сприйняття і переживання діючих індивідів в контексті ситуації; через загальні інваріантні характеристики ситуації; через опис конкретних ситуацій.

Для того, щоб зрозуміти дослідження релігійної віри, пов'язані як з розумовим, так і 3 фізичним здоров'ям, нам потрібно осягнути проблему життєвих критичних ситуацій у людей похилого віку. Старість є важливим стресовим чинником для багатьох людей. Відомий американсько-німецький психолог Е. Еріксон останні роки життя особистості ідентифікував як боротьбу між власною цілісністю та відчаєм. Адже старіюча людина повинна протистояти ряду помітних змін та втрат: фізичні та розумові навички погіршуються, особистісна значимість знижується після виходу на пенсію, вмирають близькі люди i, нарешті, єдине, що залишається, це розуміння того, що життя може швидко закінчитись. В цей період також зростає сприйнятливість до хвороб, серед яких $є$ підвищення ймовірності раку, захворювань серця, артриту та неврологічні розлади.

Встановлення у такому ракурсі зв'язків між вірою і раціональним пізнанням відповідає одній з духовних тенденцій нашого часу, яка полягає у подоланні суперечності між вірою і мисленням. Хто хоче вірити, має навчитися іти і шляхом мислення. Віра без мислення $€$ обхідним маневром, надто далеким від справжнього Життя. Відомий православний психіатр Д. Мелехов вважав, що релігійні пе- реживання допомагають чинити опір хворобі, пристосуватися до неї, компенсувати частково психічний дефект. На думку Г. Оллпорта, психіатрія і релігія повинні тісно співпрацювати. Про психотерапевтичний потенціал релігійної віри свідчать такі дослідження. О. Венгер та О. Чабан провели обстеження 64 хворих, які знаходились на стаціонарному лікуванні в обласній клінічній психоневрологічній лікарні 3 діагностованим невротичним розладом [1, с.24]. Підбір пацієнтів проводився за критеріями феноменологічної схожості та невротичної належності психопатологічних проявів. Метою дослідження було встановлення залежності розвитку невротичного впливу ступеня релігійності на формування та особливості синдромокомплексу.

Було виділено 5 ступенів релігійності 3 відповідними критеріями: I — невіруючі; II віруючі без дотримання атрибутів віри; III віруючі $з$ нестійкими переконаннями; IV віруючі з стійкими переконаннями; V - віруючі з всеохоплюючими переконаннями. Відповідно було встановлено у І групі рівень невротизації - 38,6; психопатизації - 37,6; у II групі рівень невротизації - 32,6; психопатизації - 30,8; у III групі рівень невротизації 28,4; психопатизації - 27,1; у IV групі рівень невротизації - 20,4; психопатизації - 18,2; у V групі рівень невротизації - 16,2; психопатизації - 12,0. Було встановлено, що із зростанням інтенсифікації релігійної віри спостерігалось зниження рівнів невротизації та пси- 
хопатизації. На основі досліджень було встановлено, що віруюча людина захищена від невротичних проявів більше, ніж людина невіруюча.

Дослідження, які були проведені в США свідчать, що релігійність постійно зростає упродовж дорослішання людини. $47 \%$ респондентів у віці від 19 до 29 років відзначили, що релігія відіграє важливу роль у їхньому житті, 72\% - старше 65 вважають так само [7, с.175]. Відтак через вікову призму можна чітко відстежити зростання ролі релігійної віри під час критичних життєвих ситуацій. Ряд досліджень, які були проведені американськими вченими засвідчують, що релігійна віра допомагає літнім людям, що знаходяться у критичному стані. Наведемо приклад дослідження [7, c.183], у якому приймало участь 232 кардіопацієнти літнього віку; 21 людина з них згодом померла. Дослідники проаналізували життєві орієнтири померлих та живих за різними критеріями, які включали у себе такі аспекти особистості: соціальна взаємопідтримка, релігійна приналежність, участь у релігійних заходах, рівень релігійності пацієнтів, відчуття сили та комфорту, що надавала їм релігійна віра. Так як кількість померлих була незначною - результати були чіткими: рівень смертності серед нерелігійних був у тричі більший, ніж серед активних учасників релігійних практик. Серед тих, хто був доволі релігійним та тих, кому віра надавала силу та комфорт, смертність була значно меншою. Отже, в да- ному випадку, релігійна віра, «пом'якшуючи» екзистенційну напругу, сприяла подоланню критичної життєвої ситуації.

Зазвичай патологічні реакції горя як різновид психогенних депресій, що виникають у зв'язку зі смертю близької людини, широко поширені в похилому віці. При обстеженні осіб похилого віку, які відвідують територіальний центр соціального обслуговування, було встановлено факт частого звернення пацієнтів $з$ патологічними реакціями горя до релігійної віри та релігійної практики для полегшення критичної життєвої ситуації [5, c. 95-96]. Метою роботи було визначити можливості лікувального та реабілітаційного впливу релігійної віри в осіб літнього віку 3 патологічними реакціями горя і станами самотності, що виникли після смерті чоловіка. Об'єктом вивчення стали 42 жінки у віці від 61 до 83 років з наявністю клінічних проявів патологічних реакцій горя як варіанти психогенної депресії, що виникли після смерті чоловіка. У 10 пацієнток під час депресивного стану важкого ступеня вираженості виникали суїцидальні думки і наміри. 28 пацієнток, що залишилися самотніми, переживали гостре відчуття самотності, втрату сенсу життя, безвихідь.

До моменту смерті чоловіка 34 хворих вважали себе в тій чи іншій мірі віруючими в Бога, були воцерковленими, 8 пацієнток були невіруючими. У зв'язку зі смертю чоловіка 37 обстежених здійснювали за участю родичів релігійні обряди: відспівування небіжчика у 
церкві, поминки на 9-й і 40-й дні після смерті, часто ходили в церковний храм, старанно молилися або намагалися молитися, залишали записки за упокій, ставили свічки. Перебування в храмі, молитовний стан, занурення в релігійні уявлення та переживання чинили, за даними самозвітів хворих, заспокійливий вплив: стихав душевний біль втрати, упорядковувалися думки і уявлення, на якийсь час з'являлося почуття смирення. У багатьох виникали уявлення про вічне загробне життя, про безсмертну душу померлого, з якою можна вести уявну або вголос розмову, що й робили більшість обстежених під час частих відвідин кладовища, перебирання речей чоловіка, його фотографій. Уявне спілкування з образом померлого приносило на час полегшення душевного стану, пом'якшення депресивних розладів. Зміцнювалися думки про необхідність смирення з втратою. Все це більшою мірою було виражено в осіб з внутрішньою або близькою до неї релігійною орієнтацією. Ці пацієнтки були православними віруючими 3 дитинства або юності, виховувалися в сім'ях віруючих. Після смерті чоловіка відбувалася актуалізація релігійних ідей і уявлень, занурення в релігійні почуття і переживання, що супроводжувалося полегшенням тяжкого психічного стану. У 8 обстежених інтерес і прагнення до релігії після смерті чоловіка виникли вперше в житті. 5 з них мали вищу освіту. Втрата чоловіка i тяжкі переживання у зв'язку з нею штовхали ïx на пошуки психотерапевтичного чинника, в якості якого й виступила релігія; вони стали часто ходити до храму, читати Біблію, релігійну літературу, завдяки чому виникало почуття причетності, прилучення до вічних духовних істин. Це, в свою чергу, супроводжувалося заспокоєнням, зменшенням почуття скорботи. Регулярні щоденні молитви сприяли формуванню та поглибленню релігійного умонастрою і релігійного світосприйняття. Релігійні обряди та ритуали, які практикувалися більшістю обстежених, також мали психотерапевтичний вплив. Їх виконання супроводжувалося полегшенням психічного стану.

Все вищевикладене свідчить про позитивний вплив релігійної віри на душевнохворих. Відтак релігійна віра - це не лише внутрішнє відношення людини до світу, в результаті якого відбувається вибудова суб'єктивної реальності, а й той чинник, який стабілізує ії душевний стан, укорінює в людську буттєвість надію як пошук сенсу життя, що призводить до іншого, більш глибокого розуміння життя та світосприйняття, підносить людський потенціал на інший рівень. Тим паче, такі пошуки є важливим аспектом духовного розвитку особистості. В. Франкл цілком справедливо підкреслював: «Одначе, коли пацієнт стоїть на твердому грунті релігійної віри, годі заперечити терапевтичний ефект його релігійних переконань i, у зв'язку з цим, мобілізації його духовних ресурсів» [6, с.102]. В даній ситуації релігійна віра виконує сенсожиттєву функцію, дивовижним чином поєднуючи в єдиний ду- 
ховно-екзистенційний акт такі феномени як сенс життя та критичну життєву ситуацію. Поряд $з$ цим доцільно звернути увагу на деякі нюанси, що розмежовують ці поняття. Наявність сенсу життя не обов'язково передбачає його розгортання в релігійній царині. 3 іншого боку, певна життєва ситуація може не мати значимості сенсу життя і лише в ході іiі реалізації набуває все більшої життєвої значимості для особистості. Поняття «сенс життя» в більшій мірі відображає внутрішній зміст душевного життя людини, його духовне оприявнення. Натомісь поняття «життєва ситуація» більш тісно пов'язане з майбутнім результатом і практичною діяльністю по його досягненню. Релігійна віра - передумова здійснення, необхідна підтримка, умова релігійної активності. Для успішного здійснення діяльності недостатньо самого прийняття рішення, свідомості мотиву, доводів розуму, зусиль волі тощо. Людині необхідно наявність цілісного образу майбутнього, який підтримується і живе в ній, з яким у неї емоційний зв'язок, у який вона вірить, часто незважаючи на коливання, послаблення волі або розумні доводи.

Віру ж можна вважати цілком релігійною лише в тому випадку, коли вона $є$ центральним інтегратором свідомості та стабілізатором психічних процесів, самоцінністю. Адже віра, як упевненість, не порушує екзистенційні основи людини. Якщо зіставляти між собою віру, як складову життєвої ситуації, та релігійну віру з точки зору їх смислоутворюючої фу- нкції, то можна сказати, що перша відповідає на запитання як жити, як зберегти життя, а друга відповідає на запитання про те, навіщо потрібно жити. В даному випадку ми маємо справу з специфічною рисою релігійної віри іiі фатальністю, під якою ми розуміємо виняткове значення, яке має віра при вирішенні найбільш болючих питань людського існування. Фатальність, в свою чергу, обумовлюється, по-перше, кумулятивним ефектом релігійної віри, який синтезує як віру, якою вірять, тобто індивідуальний психологічний стан, так i віру, в яку вірять, тобто феномен соціального підсилення особистих переживань за рахунок людей з такими ж переживаннями. Іноді подібні переживання навіть викликаються у невіруючих людей. По-друге, значимість релігійної віри в особистому житті та в системі особистісної орієнтації настільки велика, що навіть зіткнення $з$ фактами, що суперечать їй, ініціюють механізми психологічного захисту, які діють в ситуаціях когнітивного дисонансу (зокрема, витіснення, ігнорування тощо). Таким чином, релігійна віра є складовою особистісних ресурсів, які можуть бути представлені як система здібностей людини для усунення протиріч особистості 3 життєвим середовищем, подолання несприятливих життєвих обставин за допомогою трансформації ціннісносмислового виміру особистості, що задає їі спрямованість і створює основу для самореалізації.

Відомі також думки, що власне навер- 
нення $є$ переходом від невір'я до глибокої й активної віри або від однієї релігії до іншої. Нерідко наверненню передує релігійна криза, що виникає найчастіше як стан смисложиттєвої, екзистенційної фрустрації, переживання безнадійного духовного занепаду, невідновного зникнення духовних цінностей, ідеалів. У такій ситуації людина почуває втрату себе, а все, що донедавна здавалось їй важливим, постає як жалюгідна метушня. Якщо вона раніше була релігійною, то насамперед відбувається глибокий перегляд її ставлення до Бога, до релігії. Людина 3 душевною гіркотою, розчаруванням і докорами собі усвідомлює, що iï спонукою до молитви була егоїстична марнота, а не щира віра, сповнена милосердям і любов'ю.

Однак ті, хто переживає релігійну кризу, здебільшого не сприймають їі як остаточну душевну катастрофу. Вони свідомо чи несвідомо, на рівні налаштування чи установки (неусвідомлюваної готовності сприймати i діяти певним чином) готові прийняти нові чи радикально оновлені духовні орієнтири, духовну підтримку. Душі таких людей щиро відкриваються відповідним щодо їх готовності орієнтирам. Це і $є$ початком духовної зміни особистості.

Висновки. Отже, релігійна віра пов'язана з екзистенційними питаннями, проблемами цінностей. Адже людина не буде вірити в те, що не має для неї смислу, особливого значення. Тому й ми вважаємо, що релігійна ві- ра - інтегративне утворення, що включає в себе не тільки емоційний, когнітивний і поведінковий компоненти, але і аспекти, пов'язані 3 ситуаційним контекстом. Адже саме в певній життєвій ситуації особистість постає у всьому різноманітті своїх проявів. Таким чином, можна виділити основний фундаментальний аспект впливу релігійної віри на особистість - iї реконструктивну дію через подолання критичної життєвої ситуації і зміни духовної перспективи, що сприяє переоцінці зв'язків у системі «релігійна віра - особистість ситуація».

\section{Перелік використаних джерел:}

1. Венгер О. П. Психологічний феномен віри при невротичних розладах / О. П Венгер, О. С. Чабан // Психиатрия и религия на стыке тысячелетий: Сборник научных работ Харьковской областной клинической психиатрической больницы № 3 (Сабуровой дачи) и Харьковской медицинской академии последипломного образования / Под общ. ред. П. Т. Петрюка, Р. Б. Брагина. Харьков, 2006. - Т. 4. - С. 24.

2. Козырева А. К. Природа веры /А.К.Козырева // Ученые записки ЛГПИ: Философские исследования. T. 365. - 1968. - C. 152-171.

3. Магнусон Д. Ситуационный анализ: эмпирические исследования соотношений выходов и ситуаций / Д. Магнусон // Психологичес-кий журнал. - 1993. -№2.- С. 29-33.

4. Мамардашвили М. К. Необходимость себя. Введение в философию. Доклады, статьи, философские заметки / М. К. Мамардашвили. - М. : Лабиринт, 1996. - 432 с.

5. Полищук Ю. И. Значение религиозной веры в преодолении реакций горя в позднем возрасте / Ю.И.Полищук // Психиатрия и религия на стыке тыся- 
челетий: Сборник научных работ Харьковской областной клинической психиатрической больницы № 3 (Сабуровой дачи) и Харьковской медицинской академии последипломного образования / Под общ. ред. П. Т. Петрюка, Р. Б. Брагина. - Харьков, 2006. - Т. 4. - C. 95-96.

6. Франкл В. Людина в пошуках справжнього сенсу. Психолог у концтаборі. / В. Франкл. - Х.: Клуб сімейного дозвілля, 2016. - 160 с.

7. Hood, Ralph W. The psychology of religion: an empirical approach / / Ralph W. Hood Jr., Peter C. Hill, and Bernard Spilka.-4th ed. - New York: The Guilford Press, 2009. - 1-205 pp.

\section{References (Transliteration):}

1. Venger $O$. P. Psyxologichnyi fenomen viry pry nevrotychnyx rozladax / O. P Venger, O. S. Chaban // Psyxyatryya y relygyya na stuke tusyacheletyi: Sbornyk nauchnux rabot Xarkovskoi oblastnoi klynycheskoi psyxyatrycheskoj bolnyczy \# 3 (Saburovoj dachy) y Xarkovskoj medycynskoj akademyiy posledyplomnogo obrazovanyya / Pod obshh. red. P. T. Petryuka, R. B. Bragyna. - Xarkov, 2006. - T. 4. - S. 24.

2. Kozireva A. K. Pryroda veri /A.K.Kozireva // Uchenie zapysky LGPY: Fylosofskye yssledovanyya. - T. 365. 1968. - S. 152-171.

3. Magnuson D. Sytuacyonnij analyz: empyrycheskye yssledovanyya sootnoshenyi vixodov y sytuacyj / D. Magnuson // Psyxologycheskyj zhurnal. - 1993. -\#2.- S. 2933.

4. Mamardashvyly M. K. Neobxodymost sebya. Vvedenye v fylosofyyu. Dokladы, staty, fylosofskye zametky/ M. K. Mamardashvyly. - M. : Labyrynt, 1996. - 432 s.

5. Polyshhuk Yu. Y. Znachenye relygyoznoj veru $\mathrm{v}$ preodolenyy reakcyi gorya $\mathrm{V}$ pozdnem vozdaste / Yu.Y.Polyshhuk // Psyxyatryya y relygyya na stuke tosyacheletyi: Sbornyk nauchnux rabot Xarkovskoj oblastnoj klynycheskoj psyhyatrycheskoj bolnyczu \# 3 (Saburovoj dachy) y Xarkovskoi medycynskoi akademyiy posledyplomnogo obrazovanyya / Pod obshh. red. P. T. Petryuka, R. B. Bragy`na. - Xarkov, 2006. - T. 4. - S. 95-96.

6. Frankl $V$. Lyudyna v poshukax spravzhnogo sensu. Psyxolog u koncztabori. / V. Frankl. - X.: Klub simejnogo dozvillya, 2016. - $160 \mathrm{~s}$.

7. Hood, Ralph W. The psychology of religion: an empirical approach / Ralph W. Hood Jr., Peter C. Hill, and Bernard Spilka.-4th ed. - New York: The Guilford Press, 2009. - 1-205 pp.

\section{Denys Predko}

PhD, department of psychology, Taras Shevchenko National University of Kyiv, Kyiv (Ukraine)

\section{Larin Dmitro}

PhD student, department of psychology, Taras Shevchenko National University of Kyiv, Kyiv (Ukraine)

\section{RELIGIOUS FAITH AS A FACTOR FOR OVERCOMING CRITICAL LIFE SITUA- TIONS}

\section{ABSTRACT}

The article focuses on the senseoriented orientation of religious faith and its possibilities in overcoming critical life situations. It is argued that religious beliefs can mitigate or overcome certain life situations, acting as an integrator and mobilizer of personal resources. It is emphasized that the therapeutic function of religious faith satisfies the psychological needs of the individual, «softens» existential tension, gives emotional relaxation and calming, stabilizes the mental state of the individual.

Productive to understand the role of religious faith as a factor in overcoming critical life situations, is the opinion of M. Mamardashvili on 
findingof a certain «point of support» in life of person, through which she carries out a spiritual and existential act related to the development of the individual and determines its activities and behavior. Religious belief is characterized by fatalism, that is, the exceptional significance it has in solving the most painful issues of human existence. Usually, the most severe critical situations of the individual are those related to the awareness of their own mortality (incurable disease, participation in combat operations, etc.) or collision with another's death (the loss of a loved one).

Religious faith in various critical situations is experienced by a person in different ways. On the one hand, it can perform a destructive action, reinforcing anxiety and depression, a sense of helplessness and hopelessness that can lead to a life crisis, and on the other hand, to give meaning to life, to make it more complete and meaningful. In any case, the collision with a critical situation is painfully experienced by a person: firstly, it changes its attitude to life, death, self and values, and secondly, forms various life strategies that help her to get out of this situation, give meaning to life, make it more complete and meaningful. Consequently, religious belief is associated with existential issues, problems of values. After all, a person will not believe in something that does not have meaning for her, a special meaning. Therefore, religious faith is an integrative entity, which is characterized by a certain personal resource, which includes not only emo- tional, cognitive and behavioral components, but also aspects related to the situational context.

Key words: religious faith, critical life situation, meaning of life, fatality, personal resource.

\section{Предко Денис Ерофеевич}

Асистент кафедры общей психологии, Киевского национального университета имени Тараса Шевченка, г. Киев (Украина)

\section{Предко Денис Ерофеевич}

Асистент кафедры общей психологии, Киевского нациионального университета имени Тараса Шевченка, 2. Киев (Украина)

\section{РЕЛИГИОЗНАЯ ВЕРА КАК ФАКТОР ПРЕОДОЛЕНИЯ КРИТИЧЕСКИХ ЖИЗ- НЕННЫХ СИТУАЦИЙ}

Аннотация. В статье исследуется смысложизненная направленность религиозной веры и раскрываются ее возможности в преодолении критических жизненных ситуаций. Утверждается, что религиозная вера способна смягчить или преодолеть определенные жизненные ситуации, выступая интегратором и мобилизатором личностных ресурсов. Отмечается терапевтическая функции религиозной веры, которая удовлетворяет психологические потребности индивида, «смягчает» экзистенциальное напряжение, оказывает эмоциональную разрядку и успокоение, стабилизирует душевное состояние личности. Продуктивным для понимания роли религиозной веры, как фактора преодоления критических жизненных ситуаций, является мнение М. Мамардашвили 
об обнаружении человеком определенной «точки опоры» в жизни, благодаря которой он осуществляет духовно-экзистенциальный акт, связанный с его развитием, деятельностью и поведением. Религиозной вере присуща фатальность, то есть исключительное значение, которое она имеет при решении наиболее болезненных вопросов человеческого существования. Обычно сильнейшими критическими ситуациями личности являются те, которые связаны с осознанием собственной смертности (неизлечимая болезнь, участие в боевых действиях и т.п.) или столкновения со смертью другого (переживания потери близкого человека). Религиозная вера в различных критических ситуациях переживается личностью по-разному. С одной стороны, она может оказать деструктивное действие, усиливая тревогу и депрессию, чувство беспомощности и безнадежности, что может привести к жизненному кризису, а с другой - придать смысл жизни, сделать ее более полной и содержательной. В любом случае столкновения с критической ситуацией болезненно переживаются личностью: во-первых, меняют ее отношение к жизни, смерти, себе и ценностям, во-вторых, формируют различные жизненные стратегии, которые помогают ей выйти из данной ситуации, придать смысл жизни, сделать ее более полной и содержательной. Поэтому религиозная вера связана с экзистенциальными вопросами, проблемами ценностей. Ведь человек не будет верить в то, что не имеет для него смыс- ла, особого значения. Поэтому религиозная вера - интегративное образование, определенный личностный ресурс, включающий в себя не только эмоциональный, когнитивный и поведенческий компоненты, но и аспекты, связанные с ситуационным контекстом.

Ключевые слова: религиозная вера, критическая жизненная ситуация, смысл жизни, фатальность, личностный ресурс.
Дата отримання статті: 17.06.2017

Дата рекомендації до друку: 20.06.2017 